abundant references to the photographs and casts illustrating the Northern Schools, as well as to the actual exhibits from those of the South, special attention necessarily being directed to the Gupta period and Amaravarti.

No stronger plea than that afforded by these guides could be put forward for the adoption of a vigorous forward policy on the educational side throughout the museums of India. As the report of the Museums Commission showed, these institutions are already places of popular resort; but it depends upon the arrangement and administration of the museum itself whether they are mere repositories of 'curios', or really serve to bring home to the people the continuity in spiritual meaning underlying objects and buildings and structures familiar to them in their daily life. In the East, the function of the archæological museum is concerned with things of which the spirit, and sometimes, if not always, the form, is still alive.

\section{Instructional Films in India}

Mr. C. F. Strickxand has recently published a paper on "Instructional Films in India" (J. Roy. Soc. Arts). They supply a ready means of education in a country which "it is not possible to make literate in the next ten years", though during that period instruction concerning good government must be acquired. Adults have to be educated and already Bengal is credited with 1,000 cinemas and 500 touring companies. But most of the films shown are nonIndian and 45 per cent of them are American. They are predominantly unsuited to Indian ideas and modes of thought. Indians do not think continually "in terms of sex emotion or crime". Some educational films are now made in India and several are on loan, but these are meant chiefly for the juvenile population. Mr. Strickland explained the requirements and limitations of the Indian adult, one of which is a pace much less rapid than that to which we are accustomed. This speed with perpetual excitement is, we note, quite unnatural, lacking the tension and relaxation which prevail in life and in the best stories of action, such as the "Three Musketeers". It is, in fact, the consequent strain on the mind which makes these pictures so easily forgotten.

\section{Totaquina}

IN a recent paper (Asiatic Res., 35, 777 ; 1939), M. Ciuca states that in its search for an anti-malarial preparation cheaper than quinine but equally efficacious, the Malaria Commission of the League of Nations instituted research into the efficacy, compared with that of quinine, of a certain number of secondary alkaloid mixtures, such as kinetum, chineto, cinchona febrifuge, etc., used in the treatment of malaria in various countries. Research carried out in more than 4,000 patients in malarious countries proved that the efficacy of preparations containing 60-80 per cent crystallizable alkaloids including 15 per cent quinine was equal to that of quinine alone. The Commission has given the name of 'Totaquina' to a new preparation which is a mixture of cinchona bark alkaloids containing at least 75 per cent crystallizable alkaloids and not less than 15 per cent quinine. The advantage of the new preparation is a distinctly lower price, which is mainly due to the method of extraction, while its efficacy is equal to or only slightly less than that of quinine.

\section{Seeing at Night}

A. PAPER by R. G. Hopkinson, of the Research Laboratories, General Electric Co., Ltd., published in the Electrical Review of March 1, on "Seeing at Night", shows that valuable progress has been made on this important subject during the last few years, esperially in connexion with black-out conditions. Under weak illumination, the response of the eye is quite different from that under normal conditions. So far as light is gathered by the lens of the eye and is brought to a focus upon the retina, it functions like a camera, the retina acting like a photographic plate in recording the scene for the brain to interpret. The retina is provided, however, with two separate kinds of receptor nerve cells, the 'cones', which usually respond to bright scenes, and the 'rods', which respond to dark scenes. In daylight the cones only function. With bright artificial light both rods and cones are working, the rods recording the shadows and the cones recording the highlights for the brain. Under black-out conditions the rods alone are functioning.

Black-out vision is much inferior to day vision for the following reasons. (1) The rods do not record colours, hence black-out vision is devoid of colour sensation; all colours appear as varying grades of black and grey. (2) There are fewor rods per unit area of the retina than there are cones. The effect is analogous to that of a newspaper reproduction of a photograph, which is made up of a number of dots and is therefore less clear than the original. This handicap is the more serious since it is just that region of the retina which normally receives the clearest image, the fovea centralis, where the rods are fewest. Hence, as many must have noticed at low illuminations, vision is often better around the periphery of the eye.

\section{New Commercial Fruits in the United States}

O. Atkins writes in the American Fruit Grower (Dec. 1939) on the utility of the wild dryland blueberry (Vaccinium vaccillans $\mathrm{Kalm}$ ) in relation to soil conservation. Experiments have shown that it has unusual erosion-resistant qualities on account of its underground shoots, which send out a mass of fine roots and bind the soil together over a large area. In addition to this useful property, the blue-black fruits promise to form a successful commercial crop, and as the plant will grow and fruit in partial shade or full sunlight it is well suited to 'hill-culture'. A systematic breeding programme is being undertaken by the U.S. Department of Agriculture and Soil Conservation Service.

The papaya (Caprica papaya L.), according to S. J. Lynch, writing in the same journal, is now being grown commercially in South Florida. The texture of the flesh is similar to that of a 